\title{
ONLINE ADOLESCENT'S SELF-DISCLOSURE AS SOCIAL MEDIA USERS: THE ROLE OF EXTRAVERSION PERSONALITY, PERCEPTION OF PRIVACY RISK, CONVENIENCE OF RELATIONSHIP MAINTENANCE, AND SELF-PRESENTATION
}

\author{
Wahyu Rahardjo, Nurul Qomariyah, Matrissya Hermita, \\ Ruddy J. Suhatril, M. Akbar Marwan, Inge Andriani \\ Center of Human and Technology (CHaT) Universitas Gunadarma \\ nurul_q@staff.gunadarma.ac.id
}

\begin{abstract}
Adolescences' excessive online self-disclosure is now a social phenomenon arising in social media use. The adolescences also tend to share their privacy. This study aims to determine whether extraversion personality, perceived privacy risks, the convenience of maintaining relationships, and online self-presentation influence selfdisclosure in adolescents. This study involved 619 adolescents (185 male and 434 female) aged 13-22 years $(M=$ $19.39, S D=1.83)$. The participants are active social media users collected from several areas in Indonesia. Multiple regression analysis is used to test the hypothesis. The results show that several variables simultaneously affect online self-disclosure in adolescents $\left(R^{2}=.422 ; F(4,614)=111.944, p<.01\right)$. However, in details, online self-presentation does not have a significant effect on online self-disclosure among adolescents. This result shows that personality factors and adolescent perceptions of the low privacy risk on social media, as well as the goal of maintaining social relations with other members of social media, encourage them to be more online disclose on social media.
\end{abstract}

Keywords: online self-disclosure; adolescents; social media

\begin{abstract}
Abstrak
Keterbukaan diri daring yang dianggap berlebihan dalam membagi hal-hal yang sifatnya privat merupakan fenomena sosial yang kian lazim dijumpai dan dilakukan oleh remaja saat menggunakan media sosial. Tujuan penelitian ini adalah mengetahui secara empiris apakah kepribadian ekstraversi, persepsi risiko privasi, kenyamanan mempertahankan hubungan, dan presentasi diri daring memengaruhi keterbukaan diri pada remaja. Penelitian ini melibatkan 619 remaja (pria sebanyak 185 orang dan perempuan sebanyak 434 orang) dengan usia 13-22 tahun $(M=19,39, S D=1,83)$ pengguna media sosial aktif yang didapat dari beberapa kota di Indonesia. Analisis regresi ganda digunakan untuk menguji hipotesis dalam penelitian ini. Hasil penelitian memperlihatkan bahwa seluruh variabel secara bersama-sama memengaruhi keterbukaan diri daring pada remaja $\left(R^{2}=0.422 ; F(4\right.$, $614)=111.944, p<.01)$. Hanya saja, jika dilihat secara satu persatu, presentasi diri daring tidak memiliki pengaruh yang signifikan terhadap keterbukaan diri daring pada remaja. Hal ini menunjukkan bahwa faktor kepribadian, dan persepsi remaja yang memersepsikan media sosial tidak terlalu berisiko secara privasi, serta tujuan mempertahankan relasi sosial dengan sesama anggota media sosial mendorong mereka untuk semakin terbuka secara daring di media sosial.
\end{abstract}

Kata kunci: online self-disclosure; adolescents; social media

\section{INTRODUCTION}

The internet users in Indonesia is overgrowing every year. Based on a survey conducted by the Indonesian Internet Providers Association (APJII) in 2018, internet utilization in Indonesia increased by $10.11 \%$, from $54.69 \%$ in 2017 to $64.8 \%$ in 2018 , of the total population of Indonesia. In adolescents aged 15 to 19 years, APJII reports that only $9 \%$ of adolescents use no internet, while $91 \%$ are active internet users. These data indicate that adolescents dominate active internet use in Indonesia. They consume the internet for 
communication purposes and access to social media (APJII, 2019).

Individuals consume social media, for various purposes, from personal to professional. People search for identity, mental health, physical health, family, social relations with other people, also political issues (Veletsianos $\&$ Stewart, 2016). Separately from being used for socialization and communication, social media is also used to promote business products (Stern \& Stalb, 2015). The behaviour of sharing information on open source social media inquiries users to register their identity and write daily activities so that the followers discover more about the users. This term is known as self-disclosure. Online selfdisclosure is an interesting cyberpsychology phenomenon to research, especially concerning individual behaviour in displaying certain behaviours on social media.

Online self-disclosure is considered beneficial in building more intimate friendships in the virtual world, and it delivers positive and exciting effects for the users (Utz, 2015). There are concerns regarding privacy and identity misuse, and possibly the user turns out to be the target for sexual abuse in a virtual world (Jordan-Conde, Mennecke, \& Townsend, 2014; Krasnova, Spiekermann, Koroleva, \& Hildebrand, 2010). However, online self-disclosure provide access for the users to get social support from followers in cyberspace and gain online social well-being to improve the quality of life (Ekasari, 2013; Huang, 2016; Valkenburg \& Peter, 2009).

The social media provide several features for updating status, encouraging individuals to unlock and share personal information (Hollenbaugh \& Ferris, 2014; Walsh, Forest, \& Orehek, 2020). Ease of using social media platforms support individuals to receive several essential information through literature, uploaded images, social media content, and links to social media pages (Hollenbaugh \& Ferris, 2014). The existence of Facebook accommodates individual needs in expressing emotions and sharing much confidential personal information (Hollenbaugh \& Ferris, 2014; Waldman, 2016).

The adolescents are recognized as a net generation because of their familiarity with technology, especially communication technology (Jordan-Conde, Mennecke, \& Townsend, 2014). Compared to adults, adolescents spend more time developing social interactions in cyberspace (Valkenburg \& Peter, 2009), primarily through social media. The first generation of social media like Friendster has long been considered influencing the adolescents' psychological conditions and attributes (Adi \& Yudiati, 2009; Ghafoor \& Niazi, 2016). It is then followed by other social media such as MySpace, Facebook, Twitter, and Instagram.

Several factors are considered can influence the behaviour of online self-disclosure, and one of them is personality. Seidman (2013) states that personality affects motivation and usage of social media. A personality trait influencing self-disclosure online is extraversion. The extraversion personality reflects many positive effects from the individual, such as positive emotions, energy, and interpersonal warmth (Costa \& McCrae, 1992). Extroverted individuals tend to build closer and intimate social networks by often sharing personal information on social media (Hollenbaugh \& Ferris, 2014). Apart from positive, there are also adverse effects by sharing private information on social media (Seidman, 2013). Nonetheless, Pentina and Zhang (2016) emphasize that people with strong extraversion personalities tend to open up more and share something positive through their social media, just like their fundamental nature.

Perceptions about privacy can influence online self-disclosure. Individuals with high privacy values in building cyber world relationships will maintain their online selfdisclosure (Chen, 2013). Several studies suggest that individuals with high online selfdisclosure tend to have a more positive 
perception about the possibility of having less privacy (Utz, 2015; Yu, Li, He, Wang, \& Jiao, 2020). The result above supports previous studies suggesting that loss of privacy is a consequence of sharing the personal information in social media or self-disclosure (Gruzd \& Hernandez-Garcia, 2018; Moll, Pieschl, \& Bromme, 2014). The study of Ji, Wang, Zhang, and Zhu (2014) states that although many adolescents are concerned about privacy issues on social media, many still perceive that privacy is not a potential threat to the internet user. The statement above is in line with the findings of a longitudinal study from Tsay-Vogel, Shanahan, and Signorielli (2016) suggesting that there is a tendency for the negative influence of privacy concerns to decrease online self-disclosure over time.

Another subject that influences online openness is the convenience of maintaining a relationship. The initial part of research from Krasnova, Spiekermann, Koroleva, and Hildebrand, (2010) using focus group discussions reveals the fact that the comfort of maintaining relationships is the most critical factor for individuals in sustaining their social relationships on the internet. For that reason, individuals tend to develop self-disclosure behaviour through sharing and uploading private information. According to Wang, Yan, Lin, and Cui (2017), maintaining warm social relations between individuals and their friends on the internet is part of the social rewards for individuals, especially when they selfdisclose on social media.

Self-presentation is considered can affect online self-disclosure behaviour. Krasnova et al. (2010) explain that the values of online self-presentation encourage individuals to open themselves in online media. Presenting self on social media is individuals' positive goals and values. These values include the desire to be friendly and honestly perceived by others on social media (Krasnova et al., 2010; Wang et al., 2017). The values of online selfpresentation influence how individuals present themselves in opening friendship and romantic relationships on social media (Krasnova et al., 2010; Ward, 2016).

From the explanation above, it can be concluded that adolescents use social media to complete their personal needs. Social media usage is beneficial and provides satisfaction for the users. The dynamic self-regulatory processing model is a frame theory for this research and explains the reason for individual self-disclosure. Reasons for self-disclosure are completing communication needs, selfexpression, and social relation (Morf \& Rhodewalt, 2001). The theory also describes the excuse of losing self-regulation on narcissistic personality type in using social media (Morf \& Rhodewalt, 2001). According to the theory, the regulatory strategy, such as the role of certain personality factors and perception of risk behaviour, and the purpose of the behaviour influence self-disclosure behaviour (Morf \& Rhodewalt, 2001; Hawk, van den Eijnden, van Lissa, \& Ter Bogt, 2019). This study considers the extraversion as a personality trait, encouraging an individual to disclose themselves on social media, and this can influence the individuals' perception about the risk. Personality is an essential factor in strengthening the urge to completing satisfaction. The greater the individual motivation is, the more insignificant is the risk perceived (Hawk, Ter Bogt, van den Eijnden, \& Nelemans, 2015; Heravi, Mubarak, \& Choo, 2018).

Some of the previously published research on online self-disclosure in Indonesia has focused on typical internal variables such as self-esteem (Adnan \& Hidayati, 2018; Prawesti \& Dewi, 2016), extrovert and introvert personality, and neuroticism (Adnan \& Hidayati, 2018; Fauzia, Maslihah, \& Ihsan, 2019), external variables such as close friendship and online interpersonal trust (Buntaran \& Helmi, 2015; Pohan \& Dalimunthe, 2017), and the usage of social media (Mailoor, Senduk, \& Londa, 2017). Meanwhile, some online self-disclosure research was conducted qualitatively (Ningsih, 2015; Suyadi, 2017). Research on 
this theme still requires evidence of other complex variables, especially from research with quantitative methods. Online selfopenness is based on individual perceptions of external variables originating from humancomputer relations, such as privacy issues and online self-presentation. Research about online self-disclosure are infrequently connected to the need for maintaining social relationships. For that reason, this study aims to examine the relationships between online self-disclosure behavior and personality extraversion, perceived privacy risk, the comfort of maintaining a relationship, and online self-representation among adolescents as internet users.

\section{METHOD}

This study's inclusion criteria are adolescents aged 13 to 22 years $(M=19.39, S D=1.83)$, junior and senior high school scholars, university students, and active social media users. The number of participants in this research was 619 from several cities. The data are collected using an online questionnaire from Google form. Table 1 shows the demographic data.

Table 1.

Demographic Data Statistic

\begin{tabular}{lccc}
\hline \multicolumn{1}{c}{ Category } & $n(\%)$ & \multicolumn{1}{c}{ Category } & $n(\%)$ \\
\hline Gender & & Most used social media & \\
Male & $185(29.88 \%)$ & Facebook & $67(10.82 \%)$ \\
Female & $434(70.11 \%)$ & Instagram & $282(45.55 \%)$ \\
Residence & & Line & $145(23.42 \%)$ \\
Jakarta & $184(29.72 \%)$ & Twitter & $21(3.39 \%)$ \\
Bekasi & $134(21.64 \%)$ & WhatsApp & $95(15.34 \%)$ \\
Depok & $98(15.83 \%)$ & Path & $3(0.48 \%)$ \\
Tangerang & $90(14.53 \%)$ & YouTube & $3(0.48 \%)$ \\
Bogor & $51(8.23 \%)$ & Others & $3(0.48 \%)$ \\
Yogyakarta & $26(4.20 \%)$ & Duration of use/ day & \\
Purwokerto & $12(1.93 \%)$ & 0-1 hours & $25(4.03 \%)$ \\
Cikarang & $3(0.48 \%)$ & $1-2$ hours & $66(10.66 \%)$ \\
Others & $21(3.39 \%)$ & $2-3$ hours & $122(19.70 \%)$ \\
Occupation & $6(0.96 \%)$ & 3-5 hours & $208(33.60 \%)$ \\
Junior High School & $90(14.53 \%)$ & Above 7 hours & $109(17.60 \%)$ \\
Senior High School & $523(84.49 \%)$ & & $89(14.37 \%)$ \\
Students & & & \\
\hline
\end{tabular}

\section{Instrument}

Online self-disclosure online is an individuals' behavior in sharing personal information on the internet. This study uses a scale from Krasnova et al. (2010) to measure online self-disclosure behavior. The scale consists of 4 items with an answer range of 1-7, ranging from absolutely inappropriate to absolutely appropriate. One example of an item is "I post a complete profile of myself on social media." This scale has a reliability of .817 .

Extraversion personality is an individual's personality trait that reflects an individual's pleasure in performing social interactions because the individual has warm characteristics, full of positive emotions such as joy and energy, and minimal negative emotions such as sadness (McCabe \& Fleeson, 2012; McCrae \& Costa, 2003; Querengasser. \& Schindler, 2014). This study uses a scale from Ramdhani (2012) to measure the extraversion personality. The scale consists of 5 items with a Likert scale response range of 1-7, ranging from absolutely inappropriate to absolutely appropriate. One example of an item is "I am a person who ... does not run out of topics to talk about". All items on this scale have good discriminatory power with reliability of .818 .

Perception of privacy risk is the belief that there are possibilities that potential negative consequences can occur related to self-disclosure 
This study uses a scale from Malhotra, Kim, and

Agarwal (2004) to measure privacy risk perception. The scale consists of 4 items with a response answer range of 1-7 ranging from absolutely inappropriate to absolutely unsuitable. One example of an item is, "I was worried that something unpleasant could happen related to what I was doing on social media." One item is insufficient to meet the item discrimination standard, and it remains three items with reliability of .627 .

The convenience of maintaining relationships is the values sensed by social media users. They consider that social media openness makes it easier and more efficient to keep themselves in good contact with their social media followers (Krasnova et al., 2010). This study uses a scale from Krasnova et al. (2010) to measure the comfort of maintaining a relationship. This scale consists of three items with an answer range of 1-7, ranging from absolutely inappropriate to absolutely appropriate. One example of an item is "Social media is a place where I feel comfortable sharing information with many people regarding the activities I do." All items on this scale have an excellent discriminatory power score with a reliability of .728 .

Online self-presentation is the values sensed by users when they could improve their self-concept related to their relationships with members on social media (Krasnova et al., 2010). This study uses a scale to measure online self-representation from Walther, Slovacek, and Tidwell (2001) consisting of 3 items, with a response range of 17 ranging from absolutely inappropriate to absolutely appropriate. One example of an item is "I try to present myself properly on social media." All items on this scale have an excellent discriminatory score with reliability of 0.786

This study involves voluntary participants.

Participants could participate in this study only if they are will and ready to be involved. The collected research data are confidential. Therefore, the research ethics is completed.
The data analysis technique used in this study is multiple regression. Before the regression analysis, the correlation between variables was analyzed. This study implements a comparative test between the variables, which involves gender differentiation to enrich this study's findings, using t-test analysis.

\section{RESULTS AND DISCUSSION}

The results of this study show that online selfdisclosure correlates with all variables, except the number of social media owned by the participants. A negative correlation emerges when online disclosure is associated with the perception of privacy risk. The results mean that the greater the participants perceive the possibilities of privacy leaks in social media, the more closed they will be. However, the older the participants are, the more closed they will be on social media. Other results show that the convenience of maintaining relationships, online self-presentation, and extraversion personality is positively correlated with online self-disclosure. Table 2 shows all the correlation results.

The regression analysis results show that the effect of all variables, such as the perception of privacy risk, the convenience of having online relationships, online self-presentation, and extraversion personality, influence online selfdisclosure by $R^{2}=.422$ with $F(4,614)=111.944$ $(p<.01)$. An outstanding result is the effect of each variable on online self-disclosure. All independent variables influence online selfdisclosure, except online self-presentation. For a more precise result, Table 3. represents the result.

The comparative test results as an additional analysis show several significant differences in all the variables, including the number of social media owned by the participant based on gender differentiation. However, no significant differences are found in online self-disclosure and the convenience of maintaining relationships based on gender. Table 4 shows the comparative test results. 
Table 2.

Correlation Between Variables

\begin{tabular}{cccccccc}
\hline & OSD & PPR & CMR & OSP & EP & Age & NoSO \\
\hline OSD & & & & & & & \\
PPR & $-.464^{* *}$ & & & & & & \\
CMR & $.580^{* *}$ & $-.346^{* *}$ & & & & & \\
OSP & $.303^{* *}$ & $-.262^{* *}$ & $.384^{* *}$ & & & & \\
EP & $.201^{* *}$ & $-.090^{*}$ & $.217^{* *}$ & $.385^{* *}$ & & & \\
Age & $-.177^{* *}$ & $-.211^{* *}$ & $-.139^{* *}$ & -.029 & .063 & & \\
NoSO & -.047 & .024 & -.054 & $.132^{* *}$ & $.135^{* *}$ & .057 & \\
$M$ & 14.57 & 13.31 & 15.84 & 15.09 & 23.79 & 19.39 & 4.58 \\
$S D$ & 5.28 & 3.73 & 3.32 & 3.04 & 4.96 & 1.83 & 1.65 \\
\hline
\end{tabular}

Note. OSD $=$ online self-disclosure, $\mathrm{PPR}=$ perception of privacy risk, $\mathrm{CMR}=$ convenience of maintaining relationship, OSP $=$ online self-presentation, $\mathrm{EP}=$ extraversion personality, $\mathrm{NoSO}=$ the number of social media owned by participants. $* p<.05 . * * p .01$.

Table 3.

Regression Analysis of The Variables

\begin{tabular}{|c|c|c|c|c|c|}
\hline \multirow[b]{2}{*}{ Model } & \multicolumn{2}{|c|}{$\begin{array}{c}\text { Unstandardized } \\
\text { Coefficients }\end{array}$} & \multirow{2}{*}{$\begin{array}{c}\text { Standardized } \\
\text { Coefficients } \\
b^{*}\end{array}$} & \multirow[t]{2}{*}{$t$} & \multirow[t]{2}{*}{$p$} \\
\hline & $b$ & $S E$ & & & \\
\hline 1 (Constant) & 6.193 & 1.449 & & 4.275 & .000 \\
\hline Perception of Privacy Risk & -.417 & .047 & -.294 & -8.895 & .000 \\
\hline $\begin{array}{l}\text { Convenience of Maintaining } \\
\text { Relationship }\end{array}$ & .718 & .055 & .452 & 13.032 & .000 \\
\hline Online Self-presentation & .041 & .062 & .023 & .658 & .511 \\
\hline $\begin{array}{l}\text { Extraversion Personality } \\
\text { a. Dependent Variable: Online Self- } \\
\text { disclosure }\end{array}$ & .081 & .036 & .076 & 2.285 & .023 \\
\hline
\end{tabular}

Table 4.

Comparison Between Variables Based on Gender

\begin{tabular}{lccc}
\hline & Male & Female & $t$ \\
\hline Online self-disclosure & $15.15(4.81)$ & $14.32(5.46)$ & $1.804^{\dagger}$ \\
Perception of privacy risk & $13.82(3.24)$ & $13.09(3.90)$ & $2.232^{*}$ \\
The convenience of maintaining a & $16.05(3.00)$ & $15.75(3.45)$ & $1.010^{\dagger}$ \\
relationship & & & \\
Online self-representation & $14.15(3.06)$ & $15.49(2.95)$ & $-5.088^{* *}$ \\
Extraversion personality & $23.18(4.84)$ & $24.06(4.99)$ & $-2.019^{*}$ \\
Number of social media & $3.82(1.36)$ & $4.90(1.66)$ & $-7.759 * *$ \\
\hline
\end{tabular}

Note. ${ }^{*} p<.05 .{ }^{*} p<.01 .{ }^{\dagger} p=$ non-significant.

The results of this study indicate the effect of extraversion personality on online selfdisclosure. The study of Hollenbaugh and Ferris (2014) found that extraversion personality encourages individuals to uncover themselves more deeply and intensely through social media. Another finding by Pentina and Zhang (2016) explains that extraversion personality makes individuals comfortable to share many positive things about themselves on social media.

According to Chen, Widjaja, and Yen (2015), personality and need of affiliation collaborate in encouraging individuals to be more disclose on social media. The extraversion personality 
leads to sharing many positive things. If popularity, having many friends, and getting more intimate online relationships to become the individuals' purpose, they will quickly identify it more comfortable to open themselves on social media (AmichaiHamburger \& Vinitzky, 2010; Chen, Widjaja, \& Yen, 2015). Furthermore, AmichaiHamburger and Vinitzky (2010) state that personal pieces of information commonly shared by individuals with prominent extraversion personalities is information about current activities, interests, hobbies, quotes, or favorite words describing their concern.

Perceptions of privacy risk also play an essential role in influencing an individual's online self-disclosure behavior. The negative correlation between the perceived privacy risk and self-disclosure behavior in this study supports the study by Krasnova et al. (2010). The high level of perceived privacy risk occurs when individuals have a strong awareness of the importance of maintaining privacy on social media. The awareness will develop a sense of trust whether an individual shares personal and open information on social media or not (Taddei \& Contena, 2013; Zlatolas, Welzer, Hericko, \& Holbl, 2015). The lesser the individual perceives the high privacy leak, the more disclose he will be on social media. If individuals perceive low privacy leakage risk, they voluntarily provide such personal information in cyberspace (Myerscough, Lowe, \& Alpert, 2006). The perception of privacy risk is essential, and today's social media provides multiple security features and guarantees privacy security. The more secure the features on the internet are visually proven and perceived by individuals, the less the individuals care about privacy risks because of safety feeling (Kim, Park, Park, \& Ahn, 2019; Sheng, Felix, Saravade, Siguaw, Ketron, Krejitz, \& Duchowski, 2020), mostly they will online disclose themselves.

A very diverse friend on social media could negatively influence the perceived risk of privacy on online self-disclosure. In this context, divers mean that the friend list on social media on the friendship list consists of close friends, acquaintances, or maybe even unfamiliar ones. Individuals do not consider privacy an important issue because they take the risk to accept friendship from many people they do not know. Another issue is that most participants in this study did not apply strict privacy settings in accepting online friendships. Personal self-disclosure with less intimate friendship privacy settings tend not to be high (Utz \& Kramer, 2009). However, this phenomenon is reasonable in cyberspace relations because the 'friend' category can also be a stranger for the social media owner. The owner does not recognize well their follower (Utz, 2015).

The participants' empirical mean of privacy is still in the moderate category $(\mathrm{ME}=13.31)$. However, the hypothetical mean $(\mathrm{MH})$ is = 12. The result means that even though the participants aware of privacy risk, private information is still online disclosed. Hallam and Zanella (2017) define this as a privacy paradox. The privacy paradox is the gap between the existence of significant privacy issues on social media and the intensity of self-disclosure behavior. The paradox exists when the individuals do not consider the negative consequences of privacy sharing on social media because the negative consequences are not yet clear. Conflict is a situation in which bad behavior should be rewarded immediately, while the adverse effects of reward will be considered later.

The convenience of maintaining relationships is also a reason for online self-disclosure. The study of Krasnova et al. (2010) found that the comfort of maintaining relationships on social media is an influential factor for online privacy disclose. A comfortable feeling of establishing social contacts on the internet encourages individuals to maintain their online social relationships (Pang, 2018). Moreover, when the extraversion personality is involved in understanding the relationship between the convenience of maintaining 
relationships, the correlations among variables become obvious. Individuals with extraversion personalities usually like to make friends in real life, use the internet to remain in contact, and maintain relationships online (Ross et al., 2009). Online socialization is typical behavior for individuals to maintain communication and relationships with other people on their social media friendship list (Hughes, Rowe, Batey, \& Lee, 2012).

The absence of a significant effect of online self-presentation on online self-disclosure is essential to discuss. This result means that online self-disclosure is not necessarily accompanied by adequate and proper selfrepresentation. Several individuals prefer to present their real selves rather than their ideal self on online social media representation (Michikyan, Dennis, \& Subrahmanyam, 2014). Most individuals whose social media members are only close friends and family; good self-presentation is not necessarily needed because individuals can appear honestly (Utz \& Kramer, 2009).

Personal and social issues uploaded on social media status are also another topic for concern (Attrill \& Jalil, 2011). Control on sharing personal information on online media impacts online self-presentation and self-disclosure. When social media contains close and personally familiar people, the control of sharing personal information behavior is no longer necessary to consider (Contena, Loscalzo, \& Taddei, 2015). Bevan-Dye and Akpojivi (2015) found that trust in familiar figures plays a critical role in self-disclosure behavior. Consequently, with familiar members on social media, the always proper self-representation is not frequently considered.

The value of online self-presentation in this study is positive, and it means that individuals are trying to present themselves positively and adequately on the internet. Liu and Brown's
(2014) confirm that online self-disclosure allows users to get positive feedback from others. On the other hand, there is a possibility that the participants have negative online selfpresentation values so that they will display negative posts such as complaining and grumbling. A study by Rains and Brunner (2015) found that when individuals open themselves up through negative posts, they will get more likes and social support from others than posting neutral or even positive statuses on their social media.

This study's findings illustrate that extraversion personality functions the same as narcissism in encouraging individuals to perceive online self-disclosure as less risky and essential because it is useful for maintaining social relationships. Selfdisclosure and privacy have the same antecedents, namely, failure to self-regulate (Reed, Spiro, \& Butts, 2016). The drive for personality factors and the great need to maintain social relations is also related to individuals' ability to control their behavior. Extraversion encourages individuals to get satisfaction without frequently considering risk (Lun \& Yeung, 2019).

The results of additional analysis through comparative studies also reveal some interesting findings. Although it differs insignificantly, it appears that males' online self-disclosure is higher than females' This finding disproves several previous findings which state that females are more open on social media than males (Kisilevich, Ang, \& Last, 2012; Special \& Li-Barber, 2012; Suyadi, 2017). However, some studies found no differences in online self-disclosure on social media between males and females (Buntaran \& Helmi, 2015; Sheldon, 2013). Some studies have found that mals disclose personal information more widely on the internet than females (Ahmed, 2015). The value of popularity may influence the higher scores of online disclosure on males than females. The need for popularity influences 
online self-disclosure among social media users (Chen, Widjaja, \& Yen, 2015).

This study found that the perception of privacy risk in males was higher than that of females. This difference is significant. This finding supports the previous findings by van der Schyff, Flowerday, and Furnell (2020). Gender is included in the cultural differentiation issue that affects the perceived risk of privacy, so it is very plausible that research findings vary (Reed, Spiro, \& Butts, 2016). Reed, Spiro, and Butts (2016) also found that females tend to more easily change their social media privacy settings to be more closed than men. Cultural differences are the reason for variation research findings regarding the relationship between gender and perceived privacy risks.

This study found that the perception of privacy risk in males was higher than females. This difference is significant. This finding supports the previous findings by van der Schyff, Flowerday, and Furnell (2020). Gender is included in the cultural differentiation issue that affects the perceived risk of privacy, so it is very plausible that research findings vary (Reed, Spiro, \& Butts, 2016). Reed, Spiro, and Butts (2016) also found that females tend to more easily change their social media privacy settings to be more closed than males. Cultural differences impact the variation of research finding on the relationship between gender and perceived privacy risk.

In this study, no significant difference was found in the convenience of maintaining a relationship based on gender. However, it appears that the score of maintaining relationships on males is higher than females. This finding contrasts with the theory stating that females prefer to express their communication more clearly when establishing relationships and struggle to maintain social relationships than males (Merchant, 2012). Maintaining relationships is higher on males than females because the built relationships lead to friendship and discussion. In this case, men will show more effort than women (Sheldon, 2013).

There is no significant difference between males and females online self-presentation. However, it appears that females tend to be more intense in online self-disclosure than males. This intensity can occur because there is a tendency for women to be more hesitant about receiving negative responses from others if they do not present a more passionate, friendly, and appropriate. As a result, self-presentation emphasizes the persona more to get a fair assessment (Sutton, Robinson, \& Farral, 2011).

Females have more social media than males. This finding is in line with the research of Buntaran and Helmi (2015). The difference in the number of social media based on gender differences is also related to the online selfpresentation. Females very concern about self-positive images and tend to display on social media. Women tend to show themselves as attractive, friendly, and an appropriate presentation must be done to present an excellent online self-presentation (Lyu, 2016). The possibility of having a large number of social media is also part of the effort to present an appropriate selfpresentation to friends in cyberspace.

This study has several limitations. First, this study did not ask about the participants' privacy settings. Glasshouse setting are essential actions affecting the communication method in social media, the individuals' online openness (Contena, Loscalzo, \& Taddei, 2015; Green, Wilhelmsen, Wilmots, Dudd, \& Quinn, 2016; Masur \& Scharkow. , 2016), perception of privacy risk, and online selfpresentation. Second, this study did not consider social media's dual role, such as private or store accounts. If the individuals are selling a product, personal information exposure to the consumers is essential in gaining consumers' trust (Latiff \& Safiee, 2015; Stern \& Salb, 2015). Therefore, social media owners' openness is a basis for consumers to buy products and not establish 
friendship social relations. Third, the management of self-disclosure has not been considered. Masur and Scharkow's (2016) found that individuals aware that they can manage personal things uploaded. The more personal information must be shared, the less frequent it will be shared. On the other hand, general information is shared more often than personal information.

\section{CONCLUSION}

Internal factors such as extraversion personality do not always significantly influence specific behaviors like online disclosure. Online self-disclosure is a complex variable because it provides multiple meanings to individuals. Even though it is open to build friendships and make friends, privacy must be considered before individuals disclose themselves online. On the other hand, online self-disclosure is intensely carried out by adolescents to maintain friendship and social relationships on their social media. The absence of online self-presentation effects on online self-disclosure requires a more indepth study. However, adolescents' selfdisclosure is essential to maintain social relations with fellow virtual world community members. Self-control, such as efforts to limit the duration of social media use, friendship selection, and private conversation, is crucial. With self-control adolescents can classify the private, not to be shared information and the general information they can share. Selfcontrol is significant to prevent adverse consequences, such as misuse of personal information and data, mostly illegal cyber activities, do not occur.

\section{REFERENCES}

Adi, P. S., \& Yudiati, M. E. A. (2009). Harga diri dan kecenderungan narsistik pada pengguna Friendster. Jurnal Psikologi, 3(1), 25-32.

Ahmed, A. A. A. M. (2015). "Sharing is caring": Online self-disclosure, offline social support, and social network site usage in the UAE. Contemporary Review of the Middle East, 2(3), 192-219. doi:10.1177/2347798915601574

Amichai-Hamburger, Y., \& Vinitzky, G. (2010). Social network use and personality. Computers in Human Behavior, 26, 12891295. doi:0.1016/j.chb.2010.03.018

APJII. (2019). Penetrasi dan profil perilaku pengguna intenet Indonesia. Jakarta

Attrill, A., \& Jalil, R. (2011). Revealing only the superficial me: Exploring categorical

self-disclosure online. Computers in Human Behavior, 27, 1634-1642. doi: 10.1016/j.chb.2011.02.001

Bevan-Dye, A. L. \& Akpojivi, U. (2015). South African generation Y students' selfdisclosure on Facebook. South African Journal of Psychology, 46(1), 114-129. doi: $10.1177 / 0081246315602645$

Buntaran, F. A. A., \& Helmi, A. F. (2015). Peran kepercayaan interpersonal remaja yang kesepian dalam memoderasi pengungkapan diri pada media jejaring sosial online. Gadjah Mada Journal of Psychology, 1(2), 106-119. https://doi.org/10.22146/gamajop.7348

Chen, J. C., Widjaja, A. E., \& Yen, D. C. (2015). Need for affiliation, need for popularity, self-esteem, and the moderating effect of Big Five personality trait affecting individuals' self-disclosure on Facebook. International Journal of Human-Computer Interaction, 31, 815831. doi:10.1080/10447318.2015.1067479

Contena, B., Loscalzo, Y., \& Taddei, S. (2015). Surfing on social network sites: A comprehensive instrument to evaluate online self-disclosure and related attitudes. Computers in Human Behavior, 49, 30-37. doi:10.1016/j.chb.2015.02.042

Costa, Jr., P. T., \& McCrae, R. R. (1992). Four ways five factors are basic. Personality and Individual Differences, 13(6), 653-665. https://doi.org/10.1016/01918869(92)90236-I 
The Role of Extraversion Personality, Perception of Privacy Risk

Convenience of Relationship Maintenance and Self-Presentation

Ekasari, N. (2013). Hubungan antara pengungkapan diri melalui Blackberry Messenger dan kualitas hidup pada remaja. Calyptra, 2(2), 1-11.

Ghafoor, F., \& Niazi, M. A. (2016). Using social network analysis of human aspects for online social network software: A design methodology. Complex Adaptive System Modeling, 4(14), 1-19. doi: 10.1186/s40294-016-0024-9

Green, T., Wilhelmsen, T., Wilmots, E., Dodd, B., \& Quinn, S. (2016). Social anxiety, attributes of online communication and self-disclosure across private and public Facebook communication. Computers in Human Behavior, 58, 206-213. http://dx.doi.org/10.1016/j.chb.2015.12.06 6

Gruzd, A., \& Hernandez-Garcia, A. (2018). Privacy concerns and self-disclosure in private and public uses of social media. Cyberpsychology, Behavior, and Social Networking, 21(7), 418-428. doi: 10.1089/cyber.2017.0709

Hallam, C., \& Zanella, G. (2017). Online selfdisclosure: The privacy paradox explaines as a temporally discounted balance between concerns and rewards. Computers in Human Behavior, 68, 217-227. doi:10.1016/j.chb.2016.11.033

Hawk, S. T., ter Bogt, T. F. M., van den Eijnden, R. J. J. M., \& Nelemans, S. A. (2015). Too little power, too much information! Power, narcissism, and adolescents' disclosure on social networking sites. Computers in Human Behavior, 52, 72-80. doi:10.1016/ j.chb.2015.05.014

Hawk, S. T., van den Eijnden, R. J. J. M., van Lissa, C. J., \& ter Bogt, T. F. M. (2019). Narcissistic adolescents' attention seeking following social rejection: Link with social media disclosure, problematic social media use, and smartphone stress. Computers in Human Behavior, 92, 65-75. doi:10.1016/j.chb.2018.10.032
Heravi, A., Mubarak, S., \& Choo, K. K. R. (2018). Information privacy in online social network: Uses and gratification perspective. Computer in Human Behavior, 84, 441-459.

Hollenbaugh, E. E., \& Ferris, A. L. (2014). Facebook self-disclosure: Examining the role of traits, social cohesion, and motives. Computers in Human Behavior, 30, 50-58. doi:10.1016/j.chb.2013.07.055

Huang, H. Y. (2016). Examining the beneficial effects of individual's selfdisclosure on the social network site. Computers in Human Behavior, 57, 122132. doi: 10.1016/j.chb.2015.12.030

Hughes, D. J., Rowe, M., Batey, M., \& Lee, A. (2012). A tale of two sites: Twitter vs.

Facebook and the personality predictors of social media usage. Computers in Human

Behavior, 28, 561-569. doi:10.1016/j.chb.2011.11.001

Ji, Y., Wang, G.J., Zhang, Q., \& Zhu, Z.H. (2014). Online social networking behaviors among Chinese younger and older adolescents: The influence of age, gender, personality, and attachment style. Computers in Human Behavior, 41, 393402. doi:10.1016/j.chb.2014.08.011

Jordan-Conde, Z., Mennecke, B., \& Townsend, A. (2014). Late adolescent identity definition and intimate disclosre on Facebook. Computers in Human Behavior, 33, 356-366. doi:10.1016/j.chb.2013.07.015

Krasnova, H., Spiekermann, S., Koroleva, K., \& Hildebrand, T. (2010). Online social networks: Why we disclose. Journal of Information Technology, 25, 109-125. doi: 10.1057/jit.2010.6

Latiff, Z. A., \& Safiee, N. A. S. (2015). New business set up for branding strategies on social media - Instagram. Procedia Computer Science, 72, 13-23. doi:10.1016/j.procs.2015. 12.100 
Lun, V. M. C., \& Yeung, J. C. (2019). Elaborating the effect of culture on the relations of extraversion and neuroticism to life satisfaction. Personality and Individual Differences, $\quad 142, \quad 79-84$. doi:10.1016/j.paid.2019.01.039

Lyu, S. O. (2016). Travel selfies on social media as objectified self-presentation. Tourism Management, 54, 185-195. doi:10.1016/j.tourman.2015.11.001

Mailoor, A., Senduk, J. J., \& Londa, J. W. (2017). Pengaruh penggunaan media sosial Snapchat terhadap pengungkapan diri mahasiswa jurusan ilmu komunikasi Fakultas Ilmu Sosial dan Ilmu Politik Universitas Sam Ratulangi. Acta Diurna, 6(1), 1-17.

Malhotra, N. K., Kim, S. S., \& Agarwal, J. (2004). Internet users' information privacy concerns (IUIPC): The construct, the scale, and a causal model. Information Systems Research, 15(4), 336-355. doi: 10.1287/isre. 1040.0032

Masur, P. K., \& Scharkow, M. (2016). Disclosure management on social network sites: Individual privacy perceptions and user-directed privacy strategies. Social Media + Society, 2(1), 1-13. doi: $10.1177 / 2056305116634368$

McCabe, K. O., \& Fleeson, W. (2012). What is extraversion for? Integrating trait and motivational perspectives and identifying the purpose of extraversion. Psychological Science, 23(12), 1498-1505. doi: $10.1177 / 0956797612444904$

McCrae, R. R., \& Costa, Jr., P. T. (2003). Personality in adulthood: A five-factor theory perspective. New York: Guilford Press.

Merchant, K. (2012). How men and women differ: Gender differences in communication styles, influences tactics, and leadership styles (Unpublished master's thesis). Claremont McKenna College, Claremont.
Michikyan, M., Dennis, J., \& Subrahmanyam, K. (2014). Can you guess who I am? Real, ideal, and false self-presentation on Facebook among emerging adults. Emerging Adulthood, 3(1), 55-64. https://doi.org/10.1177/216769681453244 2

Moll, R., Pieschl, S., \& Bromme, R. (2014). Trust into collective privacy? The role of subjective theories for self-disclosure in online communication. Societies, 4, 77784. doi: 10.3390/soc4040770

Morf, C. C., \& Rhodewalt, F. (2001). Unraveling the paradoxes of narcissism: A dynamic self- regulatory processing model. Psychological Inquiry, 12, 177-196.

Myerscough, S., Lowe, B., \& Alpert, F. (2006). Willingness to provide personal information online: The role of perceived privacy risk, privacy statements and brand strength. Journal of Website Promotion, 2, 115-140.

doi: $10.1080 / 15533610802104182$

Ningsih, W. (2015). Self-disclosure pada media sosial: Studi deskriptif pada media sosial anonim LegaTalk (Skripsi tidak diterbitkan). Sultan Ageng Tirtayasa, Banten.

Pentina, I., \& Zhang, L. (2016). Effects on social support and personality on emotional disclosure on Facebook and in real life. Behaviour \& Information Technology, 1-9. doi: 10.1080/0144929X.2016.1258086

Querengasser, J., \& Schindler, S. (2014). Sad but true? How induced emotional states differentially bias self-rated Big Five personality traits. BMC Psychology, 2(14), 1-8. doi: 10.1186/2050-7283-2-14

Rains, S. A., \& Brunner, S. R. (2015). The outcomes of broadcasting self-disclosure using new communication technologies: Responses to disclosure vary across one's social network. Communication Research, 1-29. doi: 10.1177/0093650215598836 
Online Adolescent's Self-Disclosure as Social Media Users:

The Role of Extraversion Personality, Perception of Privacy Risk

Convenience of Relationship Maintenance and Self-Presentation

Ramdhani, N. (2012). Adaptasi bahasa dan budaya Inventori Big Five. Jurnal Psikologi, 39(2), 189-207.

Reed, P. J., Spiro, E. S., \& Butts, C. T. (2016). Thumbs up for privacy? Differences in online self-disclosure behavior across national culture. Social Science Research, 59 , 155-170.

doi:

10.1016/j.ssresearch.2016.04.022

Ross, C., Orr, E. S., Sisic, M., Arseneault, J. M., Simmering, M. G., \& Orr, R. R. (2009). Personality and motivations associated with Facebook use. Computers in Human Behavior, 25, 578-586. doi: 10.1016/j.chb.2008.12.024

Seidman, G. (2013). Self-presentation and belonging on Facebook: How personality influences social media use and motivations. Personality and Individual Differences, 54(3), 402-407. doi:10.1016/j.paid.2012.10.009

Sheldon, P. (2013). Examining gender differences in self-disclosure on Facebook versus face-to-face. The Journal of Social Media in Society, 2(1), 88-105.

Special, W. P., \& Li-Barber, K. T. (2012). Self-disclosure and student satisfaction in Facebook. Computers in Human Behavior, 28, 624-630. 10.1016/j.chb.2011.11.008

Stern, T., \& Salb, D. (2015). Examining online social newtork use and its effect on the use of privacy settings and profile disclosure. Bulletin of Science, Techology

\& Society, 35, 25-34. doi:0.1177/0270467615596890

Sutton, R. M., Robinson, B., \& Farrall, S. D. (2011). Gender, fear of crime, and selfpresentation: An experimental investigation. Psychology, Crime \& Law, 17(5), 421-433. doi: $10.1080 / 10683160903292261$

Suyadi, A. A. (2017). Media sosial dan selfdisclosure: Studi deskriptif kualitatif pengungkapan diri terhadap mahasiswa ilmu komunikasi Universitas Muhammadiyah Surakarta dalam mengakses Path berdasarkan gender (Skripsi tidak diterbitkan). Universitas Muhammadiyah Surakarta, Surakarta.

Taddei, S., \& Contena, B. (2013). Privacy, trust and control: Which relationships with online self-disclosure? Computers in Human Behavior, 29, 821-826. doi: 10.1016/j.chb.2012.11.022

Tsay-Vogel, M., Shanahan, J., \& Signorielli, N. (2016). Social media cultivating perceptions of privacy: A 5-year analysis of privacy attitude and self-disclosure behaviors among Facebook users. New Media \& Society, 20(1), 141-161. doi:10.1177/ 1461444816660731

Utz, S. (2015). The function of self-disclosure on social network sites: Not only intimate, but also positive and entertaining selfdisclosures increase the feeling of connection. Computers in Human Behavior, 45, 1-10. doi:10.1016/j.chb.2014.11.076

Utz, S., \& Kramer, N. C. (2009). The privacy paradox on social nertwork sites revisited: The role of individual characteristics and group norm. Cyberpsychology: Journal of Psychosocial Research on Cyberspace, 3(2).

https://cyberpsychology.eu/article/view/42 23/ 3265

Valkenburg, P. M., \& Peter, J. (2009). Social consequences of the internet for adolescents: A decade of research. Current Direction in Psychological Science, 18(1), 1-5. doi: 10.1111/j.14678721.2009.01595.x

Veletsianos, G., \& Stewart, B. (2016). Discreet opennes: Scholars' selective and intentional self-disclosure online. Social Media + Society, 2(3), 1-11. doi: $10.1177 / 2056305116664222$

Waldman, A. E. (2016). Privacy, sharing, and trust: The Facebook study. Case Western Reserve Law Review, 67(1), 193-233. 
Walther, J. B., Slovacek, C. L., \& Tidwell, L. C. (2001). Is a picture worth a thousand words? Photographic images in long-term and short-term computer-mediated communication. Communication Research, 28(1), 105-134. doi:10.1177/009365001028001004

Walsh, R. M., Forest, A. L., \& Orehek, E. (2020). Self-disclosure on social media: The role of perceived network responsiveness. Computers in Human Behavior, $104,106162$. doi:10.1016/j.chb.2019.106162

Wang, L., Yan, J., Lin, J., \& Cui, W. (2017).
Let the users tell the truth: Self-disclosure intention and self-disclosure honesty in mobile social networking. International Journal of Information Management, 37, 1428-1440. doi:10.1016/j.ijinfomgt.2016. 10.006

Ward, J. (2016). Swiping, matching, chatting: Self-presentation and self-disclosure on mobile dating. Human IT, 13(2), 81-95.

Zlatolas, L. N., Welzer, T., Hericko, M., \& Holbl, M. (2015). Privacy antecedents for SNS disclosure: The case of Facebook. Computers in Human Behavior, 45, 158167. doi:10.1016/j.chb.2014.12.012 